\title{
Pisces, Perciformes, Gobiidae, Evorthodus lyricus (Girard, 1858): New record from Patos-Mirim Lagoon System, state of Rio Grande do Sul, southern Brazil
}

\author{
Morevy Moreira Cheffe ${ }^{1}$, Luis Esteban Krause Lanés ${ }^{2 *}$, Matheus Vieira Volcan ${ }^{2}$ and \\ Marcelo Dias de Mattos Burns ${ }^{3}$ \\ 1 Grupo Especial de Estudo e Proteção do Ambiente Aquático do Rio Grande do Sul (GEEPAA-RS), Divisão de Fauna, Setor de Ictiologia. Rua \\ Tiradentes 2247. CEP 96010-165. Pelotas, RS, Brazil. \\ 2 Instituto Pró-Pampa (IPPampa), Laboratório de Ictiologia. Rua Gomes Carneiro 1043. CEP 96010-610. Pelotas, RS, Brazil. \\ 3 Universidade Católica de Pelotas (UCPel), Museu de História Natural. Rua Félix da Cunha 412. CEP 96010-000. Pelotas, RS, Brazil. \\ * Corresponding author. E-mail: lelanes@gmail.com
}

\begin{abstract}
The present note records for the first time the tropical gobiid fish Evorthodus lyricus (Girard, 1858) from PatosMirim Lagoon System, state of Rio Grande do Sul, southern Brazil. Considering the known distribution of the species, and unpublished data obtained from fish collections, the present record widens the distribution of E. lyricus in $300 \mathrm{~km}$ southwards, and is the first occurrence of the species for freshwater conditions in southern Brazil.
\end{abstract}

Six of the 40 gobiid species recorded in Brazil (Menezes et al. 2003) have been reported in the Patos-Mirim Lagoon System in the southern part of the country. Bathygobius soporator (Valenciennes, 1837), Ctenogobius smaragdus (Valenciennes, 1837), Ctenogobius stigmaticus (Poey, 1860), Ctenogobius shufeldti (Jordan and Eigenmann, 1887), Gobionellus oceanicus (Pallas, 1770), and Gobiosoma parri Ginsburg, 1933 (Chao et al. 1982; Lucena and Lucena 1982; Sinque and Muelbert 1998; Burns et al. 2010). We provide herein the first record of Evorthodus lyricus (Girard, 1858) (Figure 1) in Patos-Mirim Lagoon System.

The genus Evorthodus was diagnosed by Ginsburg (1931) and Dawson (1967), and according to Pezold (2004) the synapomorphy of the genus is the presence of incisiform teeth in juveniles and females. The genus includes only two species, E. lyricus (Girard, 1858) that occurs in western Atlantic coastal and E. minutus Meek and Hildebrand, 1928 from Pacific (Dawson 1967; Foster and Fuiman 1987; Froese and Pauly 2010).

The Lyre Goby Evorthodus lyricus is classified as "euryhaline marine" species (Gunter 1956), and presents a distribution pattern similar to other peripheral tropical fish species (Foster and Fuiman 1987). The species has already included in listings of threatened fauna of North Carolina (USA) (Lindquist 1988).

On June and July 1992, seventeen individuals of $E$. lyricus were caught in drainage canal of Pontal da Barra

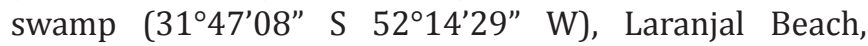
Pelotas County, Rio Grande do Sul state, southern Brazil (Figure 2A). Specimens were preserved in $70 \%$ alcohol and identified based on Menezes and Figueiredo (1985). Voucher specimens are deposited at Coleção Ictiológica Morevy Cheffe, Grupo Especial de Estudo e Proteção do Ambiente Aquático do Rio Grande do Sul (CIMC 8991, 7, 19.4-38.2 mm SL; CIMC 9048, 5, 13.8-42.7 mm SL) and Museu de Ciências e Tecnologia, Pontifícia Universidade Católica do Rio Grande do Sul (MCP 17576, 5, 20.8-30.4 $\mathrm{mm} \mathrm{SL)}$.

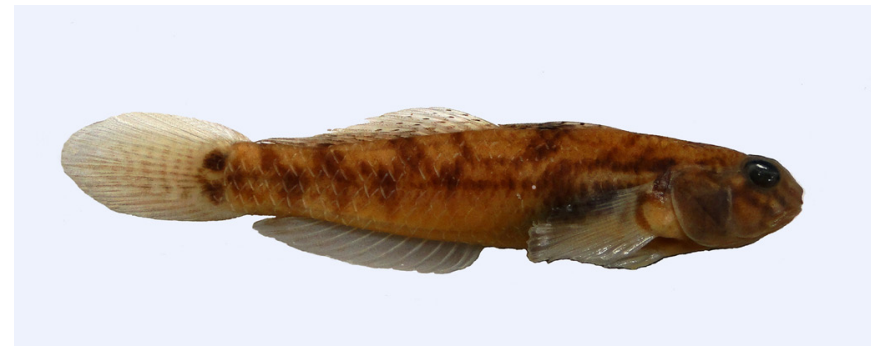

FIGURE 1. Evorthodus lyricus (CIMC 9048) captured in Rio Grande do Sul state, Patos-Mirim Lagoon System, southern Brazil.

According to the literature the species was previously recorded from North, Central, and South America in Atlantic coast, from Chesapeake Bay, Florida (USA) to Porto Belo, Santa Catarina, Brazil (Menezes et al. 2003), also recorded from Gulf of Mexico and Greater Antilles, absent from Bahamas (Froese and Pauly 2010).

As a complement of our record, we examined material from fish collection of MCP/PUCRS and confirmed the occurrence of E. lyricus for Siriú Beach (marine waters), Garopaba, Santa Catarina state (MCP 36906 and MCP 36910) and for Tramandaí Lagoon (brackish or estuarine waters), Imbé, Rio Grande do Sul state (MCP 36903 and MCP 36904) (Figure 2B), all of them south of Porto Belo (the previous southern limit of distribution of E. lyricus) (Menezes et al. 2003). Considering these records, the present study widens the distribution of E. lyricus in 300 km southwards.

The species inhabits muddy areas of bays, mainly estuarine or brackish, also marine, rarely freshwater (Kullander 2003). This occurrence of E. lyricus in Pontal da Barra swamp is the first one for freshwater from southern Brazil. In beach of São Gonçalo canal, and drainage canals of Pontal da Barra (Figure 3), the E. lyricus frequently occurs in sympatry with two other gobioids species: Ctenogobius shufeldti and Dormitator maculatus (Bloch, 1792), which was recently recorded for this same area by Volcan et al. (2010); for E. liricus, constitutes its southernmost 

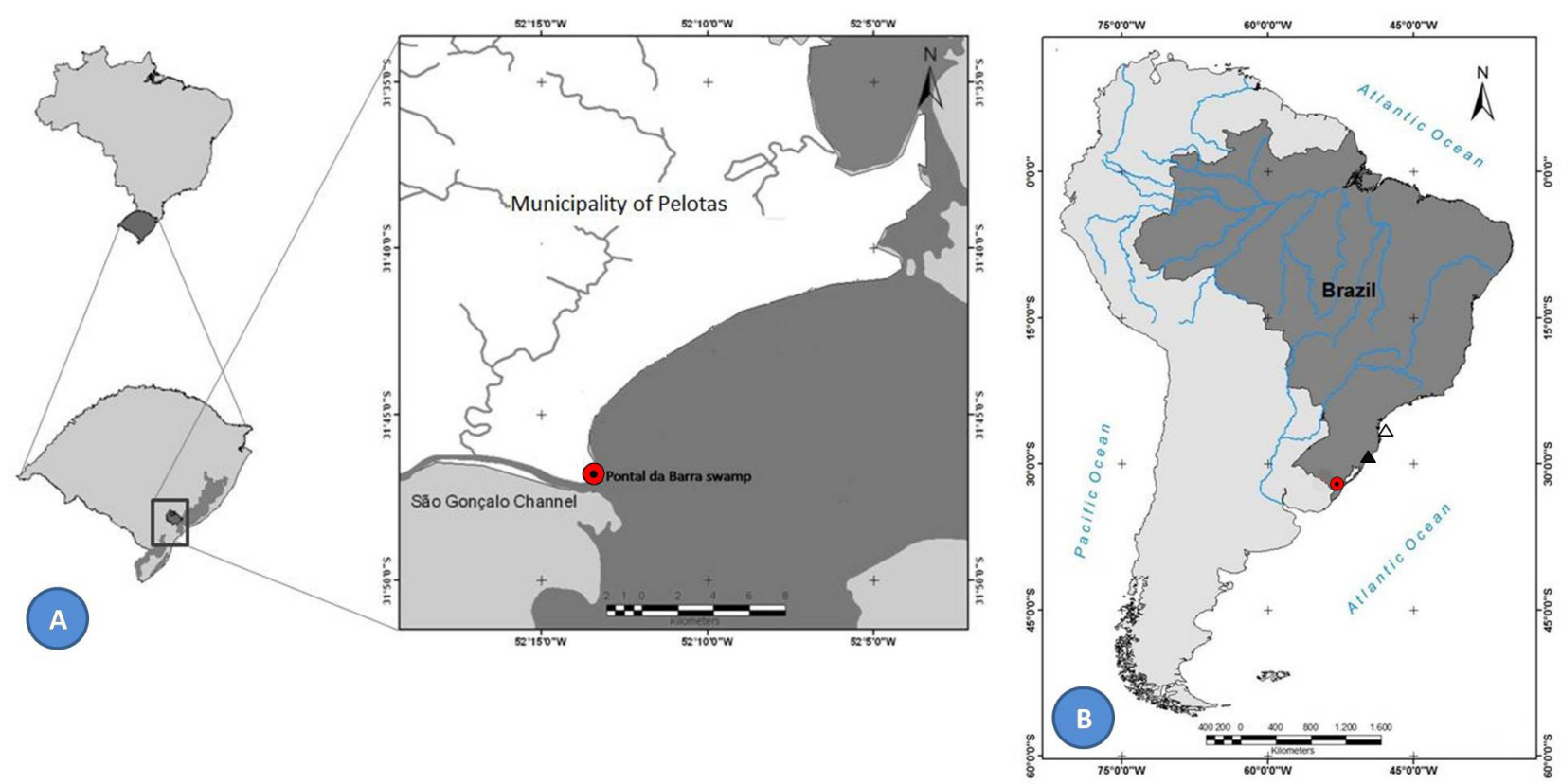

Figure 2. (A) Map showing the occurrence of Evorthodus lyricus in Patos-Mirim Lagoon System, Rio Grande do Sul state. (B) Unpublished data on the occurrence of Evorthodus lyricus in southern Brazil, obtained in the fish collection of the MCP/PUCRS. $(\Delta)$ Siriú Beach, Garopaba, Santa Catarina state (MCP 36906 and MCP 36910). (A) Tramandaí Lagoon, Imbé, Rio Grande do Sul state (MCP 36903 and MCP 36904). (S) Present record of E. lyricus for Patos-Mirim Lagoon System, Rio Grande do Sul state (CIMC 8991, CIMC 9048 and MCP 17576).

distribution. According to Foster and Fuiman (1987) the distribution of the species is probably related to coastal currents, affecting the dispersal of pelagic larvae. Evorthodus lyricus had parental care behavior, and adult males guarded egg masses, and removed physically smallsized predators from the vicinity of the burrow, previously excavated by the male. These authors suggest that the reproduction of the species is related to gradual freshening of the water during rainy seasons.

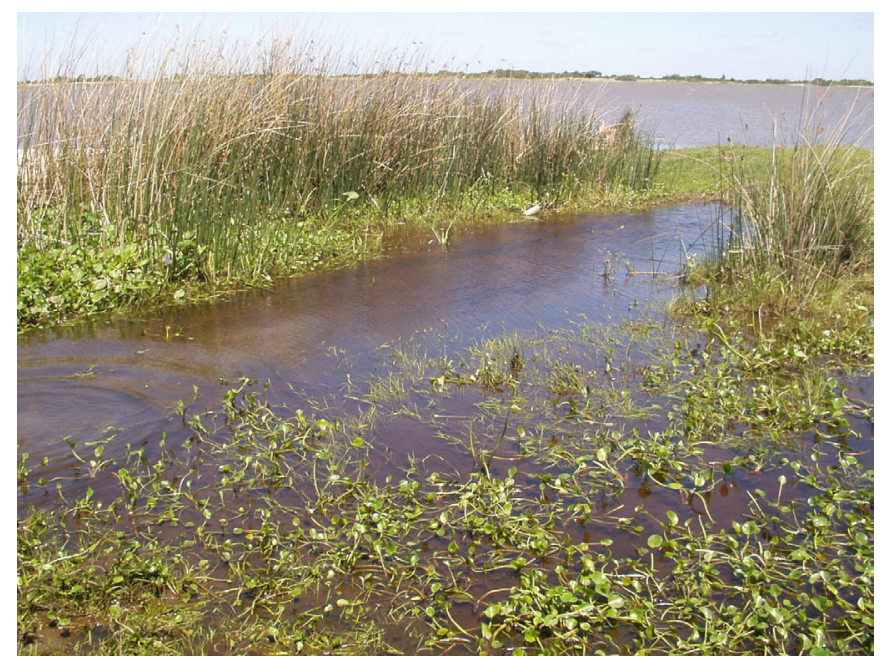

FIGURE 3. Occurrence site of Evorthodus lyricus in Pontal da Barra swamp, Patos-Mirim Laggon System, southern Brazil.

The occurrence of juvenile specimens with approximately $14 \mathrm{~mm}$ of SL indicates that $E$. lyricus breed in study area. Probably E. lyricus also occurs in other localities of Patos-Mirim Lagoon System, however more studies are needed to determine the actual conservation status of this species in the region.

Possible explanations for sporadic occurrence of Evorthodus lyricus, and other gobiid species in the PatosMirim Lagoon System include variations of salinity, inappropriate collecting methods, insufficient sampling of appropriate habitat, low abundance, and the cryptic habits of this species (Wyanski and Targett 1985; Foster and Fuiman 1987; Burns et al. 2010).

Apparently the occurrence of tropical fish in subtropical waters of the Patos-Mirim Lagoon System is related to the Brazilian Current in the Atlantic coast, which brings warm surface waters from the tropical to the subtropical region (Burns et al. 2010). Although anthropogenic factors have influence in fish distributions, the occurrence of other tropical gobioid fishes as Bathygobius soporator, Ctenogobius smaragdus, Ctenogobius stigmaticus, Gobionellus oceanicus, Gobiosoma parri, and Dormitator maculatus in Patos Lagoon, indicates that these species are autochthonous in the region, but are overlooked, and occur at low density in its southern distribution range limits.

ACKNOWLEDGMENTS: We thank the anonymous reviewer's comments, and the area editor, that encouraged the use of material deposited in the Museu de Ciências e Técnologia da Pontificia Universidade Católica do Rio Grande do Sul (MCT/PUCRS), thus increasing the scope of study, and improving the quality of the manuscript. We are grateful to $\mathrm{Dr}$. Carlos Alberto S. Lucena, curator of fish collection of the MCT/PUCRS for facilitate the examination of the material of E. lyricus.

\section{LITERATURE Cited}

Burns, M.D.M., A.M. Garcia and J.P. Vieira. 2010. Pisces, Perciformes, Gobiidae, Ctenogobius stigmaticus (Poey, 1860): new species record at Patos Lagoon estuary, state of Rio Grande do Sul, Brazil. Check List 6(1): 56-57.

Chao, L.N., L.E. Pereira. J.P. Vieira, M.A. Bemvenuti and L.P.R. Cunha. 1982. Relação Preliminar dos Peixes Estuarinos e Marinhos da Lagoa dos Patos e Região Costeira Adjacente, Rio Grande do Sul, Brasil. Atlântica 5(1): 67-75.

Dawson, C.E. 1967. Notes on the species of the goby genus Evorthodus. Copeia 1967(4): 855-857.

Foster, N.R. and L.A. Fuiman. 1987. Notes on the behavior and early life history of captive lyre gobies Evorthodus lyricus. Bulletin of Marine Science 41(1): 27-35

Froese, R. and D. Pauly (ed.). 2010. FishBase. Eletronic Database accessible at http://www.fishbase.org/search.php. Captured on 10 November 2010.

Ginsburg, I. 1931. Juvenile and sex characters of Evorthodus lyricus (fam. Gobiidae). Bulletin of the (U.S.) Bureau of Fisheries (47): 117-124. 
Gunter, G. 1956. A revised list of euryhalin fishes of North and Middle America. American Naturalist (56): 345-354.

Kullander, S.O. 2003. Family Gobiidae (Gobies); p. 657-665 In R.E. Reis, S.O. Kullander and C.J. Ferraris (ed.). Check list of the freshwater fishes of South and Central America. Porto Alegre: EDIPUCRS.

Lindquist, D.G. 1988. North Carolina fishes listed as endangered, threatened, or vulnerable. Vulnerable. Category 2. Evorthodus lyricus (Girard) lyre goby. Occasional Papers of the North Carolina Biological 1988-7: 12-13.

Lucena, C.A.S. and Z.M.S. Lucena. 1982. Catálogo dos Peixes Marinhos do Museu de Ciências da Pontifícia Universidade Católica do Rio Grande do Sul: Teleostomi (Final). Comunicações do Museu de Ciências da PUCRS, Série zoológica 25: 1-80.

Menezes, N.A. and J.L. Figueiredo. 1985. Manual de Peixes Marinhos do Sudeste do Brasil. V. Teleostei (4). São Paulo: Museu de Zoologia da Universidade de São Paulo. 105 p.

Menezes, N.A., P.A. Buckup, J.L. Figueiredo and R.L. Moura. 2003. Catálogo das Espécies de Peixes Marinhos do Brasil. São Paulo: Museu de Zoologia da Universidade de São Paulo. 158 p.

Pezold, F. 2004. Phylogenetic Analysis of the Genus Gobionellus (Teleostei: Gobiidae). Copeia 2004(2): 260-280.
Sinque, C. and J.H. Muelbert. 1998. Ictioplancton; p. 60-68 In U. Seeliger, C. Odebrecht and J.P. Castello (ed.). Os Ecossistemas Costeiros e Marinhos do Extremo Sul do Brasil. Rio Grande: Ecoscientia.

Volcan, M.V., M.M. Cheffe, L.E.K. Lanés and M.D.M. Burns. 2010. Pisces, Perciformes, Eleotridae, Dormitator maculatus (Bloch, 1792): Distribution extension for Patos-Mirim lagoon system, state of Rio Grande do Sul, Brazil. Check List 6(4): 479-480.

Wyanski, D.M. and T.E. Targett. 1985. Juvenile development of the lyre goby, Evorthodus lyricus (Girard) (Pisces: Gobiidae), with a discussion of early life history. Bulletin of Marine Science (36): 115-123.

RECEIVED: July 2010

REVISED: September 2010

ACCEPTED: November 2010

Published ONLINE: December 2010

EDITORIAL RESPONSIBILITY: Javier A. Maldonado 0. 